\title{
Screening for known mutations in EIF2B genes in a large panel of patients with premature ovarian failure
} Anne Fogli ${ }^{1}$, Fernande Gauthier-Barichard ${ }^{1}$, Raphael Schiffmann², Vien H Vanderhoof ${ }^{3}$, Vladimir K Bakalov' ${ }^{3}$, Lawrence M Nelson ${ }^{3}$ and Odile Boespflug-Tanguy*1

\begin{abstract}
Address: ${ }^{1}$ INSERM UMR 384, Faculté de Médecine, 28 place Henri Dunant BP 38, 63001 Clermont-Ferrand cedex, France, ${ }^{2}$ Developmental and Metabolic Neurology Branch, National Institute of Neurological Disorders and Stroke, National Institutes of Health, Bethesda, Maryland, USA and ${ }^{3}$ National Institute of Child Health and Human Development, National Institutes of Health, Bethesda, Maryland, USA

Email: Anne Fogli - anne.fogli@inserm.u-clermont1.fr; Fernande Gauthier-Barichard - fernande.gauthier@inserm.u-clermont1.fr; Raphael Schiffmann - RS4e@nih.gov; Vien H Vanderhoof - vanderhv@mail.nih.gov; Vladimir K Bakalov - bakalov@mail.nih.gov;

Lawrence M Nelson - nelsonl@cc1.nichd.nih.gov; Odile Boespflug-Tanguy* - odile.boespflug@inserm.u-clermont1.fr

* Corresponding author
\end{abstract}

Published: 26 October 2004

BMC Women's Health 2004, 4:8 doi:10.1 186/1472-6874-4-8

This article is available from: http://www.biomedcentral.com/l472-6874/4/8

(c) 2004 Fogli et al; licensee BioMed Central Ltd.

This is an open-access article distributed under the terms of the Creative Commons Attribution License (http://creativecommons.org/licenses/by/2.0), which permits unrestricted use, distribution, and reproduction in any medium, provided the original work is properly cited.
Received: 08 July 2004

Accepted: 26 October 2004

\begin{abstract}
Background: Premature Ovarian Failure (POF), defined as the development of hypergonadotropic amenorrhea before the age of 40 years, occurs in about I\% of all women. Other than karyotype abnormalities, very few genes are known to be associated with this ovarian dysfunction. Recently, in seven patients who presented with POF and white matter abnormalities on MRI (ovarioleukodystrophy) eight mutationswere found in EIF2B2, 4 and 5.
\end{abstract}

Methods: To further test the involvement of known mutations of EIF2B genes in POF, we screened 93 patients with POF who did not have identified leukodystrophy or neurological symptoms. We evaluated these eight mutations and two additional mutations that had been found in patients with milder forms of elF2B-related disorders. We used restriction enzymes and direct sequencing.

Results: None of the known mutations in EIF2B genes, either homozygous or heterozygous, were identified in our 93 patients with pure 46,XX POF. The upper $95 \%$ confidence limit of the proportion $0 / 93$ is $3.2 \%$.

Conclusions: We conclude that elF2B mutations, already described in cases of POF associated with white matter abnormalities, are an uncommon cause of pure spontaneous premature ovarian failure.

\section{Background}

Premature Ovarian Failure (POF) can present as a primary or secondary amenorrhea and is associated with elevated gonadotropins before 40 years of age. POF affects $1 \%$ of all women and occurs in $0.1 \%$ before the age of 30 years
[1]. POF has been associated with karyotype abnormalities, including various $\mathrm{X}$ chromosome aberrations such as Turner syndrome, which causes depletion of ovarian follicles during development [2]. While conditions such as autoimmune diseases are also associated with POF, the 
cause is unknown in about $90 \%$ of cases. However, since many affected women have a family history of the condition, predisposition to POF may be inherited [3]. To date, mutations associated with POF have been identified in a small number of genes [4], including those encoding the inhibin alpha [5], the FSH receptor [6], the LH/choriogonadotrophin receptor [7], and the forkhead transcription factor 2 [8]. No more than $10 \%$ of women with ovarian failure have mutations in these different genes [8].

Recently three of the five EIF2B genes (EIF2B2, 4 and 5) were reportedly involved in seven patients who presented with POF and white matter abnormalities on MRI (ovarioleukodystrophy) [9]. These genes encode the five subunits of the eucaryotic initiation factor 2B (eIF2B alpha to epsilon), which is involved in the first step of protein synthesis. eIF2B-related disorders include a large group of phenotypes with a recognizable MRI pattern but different clinical severities. The clinical spectrum can range from a rapid course leading to death in severe congenital forms to asymptomatic MRI findings in adult patients $[10,11]$. Ovarioleukodystrophy might present in a phase without neurological symptoms and an apparently isolated form of POF [9]. Therefore, we screened a series of 93 patients with apparently pure, karyotypically normal POF for mutations in EIF2B genes.

\section{Methods}

\section{Selection of patients with premature ovarian failure}

In the current study, we evaluated the presence of EIF2B mutations in 93 unrelated and well-characterized women with POF. An institutional review board approved the study and all participants gave a written informed consent. Referring physicians made the diagnosis of premature ovarian failure based on the following criteria: development of at least 4 months of amenorrhea before age 40 associated with two serum FSH levels in the menopausal range. Women with premature ovarian failure as a result of surgery, radiation, chemotherapy, or known karyotype abnormalities were not included in the study. There were 6 Asians, 12 Blacks, 4 Hispanics and 71 Caucasians. The median age at the onset of menstrual irregularity was 24.5 years (range 13 to 39 ). Eighteen women had a family history of POF. All women underwent a history and physical examination and laboratory screening to confirm the diagnosis of POF and all had a normal karyotype. None of the women had evidence of a neurological disorder.

\section{EIF2B mutations screening}

Genomic DNA was extracted from peripheral blood using standard procedures.

The exons of the genes EIF2B2, 4 and 5 which contain mutations found in POF patients or in milder forms of eIF2B-related disorders were amplified by the polymerase chain reaction (PCR) as previously described (Table 1)[11].

Nine mutations were tested by restriction enzymes directly on PCR products (Table 2): 500 ng of PCR products were incubated with 1 unit of specific restriction enzyme from Biolabs ${ }^{\circledast}$ Inc. for 90 minutes, according to the supplier's instructions. Restriction fragments were analyzed by standard acrylamide gel electrophoresis.

The C583T (R195C) mutation in the EIF2B5 gene was tested by direct sequencing of exon 4 as previously described [11].

Table I: Sequences of PCR primers used and their PCR conditions.

\begin{tabular}{|c|c|c|}
\hline Nucleotide change tested (gene) & Primers sequences $\left(5^{\prime}-3^{\prime}\right)$ & PCR conditions \\
\hline C5I2T (EIF2B2), C547T (EIF2B2) & $\begin{array}{l}\text { F: GCAAAACCGTTCTTAC } \\
\text { R: CCTACCCATCTCTCGTTTAT }\end{array}$ & $\begin{array}{l}\text { PCR preparation: } 1.5 \mathrm{mM} \mathrm{MgCl}, 0.225 \mathrm{mM} \mathrm{dNTP}, 0.8 \\
\mu \mathrm{M} \text { primers, I00 ng primers, I unit AmpliTaq } \\
\text { Gold }{ }^{\mathrm{TM}} \text { (Applied Biosystems), IX Taq buffer. }\end{array}$ \\
\hline 607-6I2del/insTG (EIF2B2), A638G (EIF2B2) & $\begin{array}{l}\text { F: GGAAATTATGTGCTGGATATG } \\
\text { R: ACTTTATTCTCTCACCGTGGAT }\end{array}$ & \\
\hline P243L (EIF2B4) & $\begin{array}{l}\text { F: ATGCTCAAGCTCCCTTTCAA } \\
\text { R: CTTCACAACTTACAAAGCCT }\end{array}$ & \\
\hline R374C (EIF2B4) & $\begin{array}{l}\text { F: ATTCAAGCACCTGGCATGAT } \\
\text { R: CGCTGCACTCCATCCTTATC }\end{array}$ & $\begin{array}{l}\text { PCR reaction: } 95^{\circ} \mathrm{C} 12 \mathrm{~min}, 35 \text { cycles }\left(94^{\circ} \mathrm{C} 30 \mathrm{~s}, 55^{\circ} \mathrm{C} 30\right. \\
\left.\mathrm{s}, 72^{\circ} \mathrm{C} 45 \mathrm{~s}\right), 72^{\circ} \mathrm{C} 10 \mathrm{~min}, 4^{\circ} \mathrm{C} .\end{array}$ \\
\hline TI393C (EIF2B4), TI465C (EIF2B4) & $\begin{array}{l}\text { F: TGTCCTGTAAGTAGGGGACCTT } \\
\text { R: AAGGGGTTGTGAAGTCTGGA }\end{array}$ & \\
\hline G338A (EIF2B5), C583T (EIF2B5) & $\begin{array}{l}\text { F: GAGAAGGACTGTGAGTGCTGA } \\
\text { R: GCCTTCTAAGGGGACAATAAC }\end{array}$ & \\
\hline
\end{tabular}

F: forward primer, R: reverse primer 
Table 2: EIF2B2, 4 and 5 mutations tested with restriction enzymes.

\begin{tabular}{|c|c|c|c|c|c|c|}
\hline \multirow{2}{*}{$\begin{array}{l}\text { Mutation tested: } \\
\text { nucleotides } \\
\text { changes (amino } \\
\text { acid changes) }\end{array}$} & \multirow[t]{2}{*}{ Mutated gene } & \multirow{2}{*}{$\begin{array}{l}\text { Restriction } \\
\text { enzyme used }\end{array}$} & \multirow{2}{*}{$\begin{array}{c}\text { PCR product } \\
\text { size } \\
\text { (base pairs) }\end{array}$} & \multicolumn{3}{|c|}{ Restriction profile (number of restriction fragments: their size in base pairs) } \\
\hline & & & & No mut* & Het mut* & Hom mut* \\
\hline C5I2T (SI7IF) & EIF2B2 & Hpyl88III & 251 & $\begin{array}{l}4 \text { fragments: } 51,29,16 \\
\text { and } 155 \mathrm{bp} \text {. }\end{array}$ & $\begin{array}{l}5 \text { fragments: } 51,29,16 \text {, } \\
155 \text { and } 17 \mid \text { bp. }\end{array}$ & $\begin{array}{l}3 \text { fragments: } 51,29 \text { and } \\
171 \mathrm{bp} \text {. }\end{array}$ \\
\hline $\begin{array}{l}\text { 607-6I2del/insTG } \\
\text { (M203fs) }\end{array}$ & EIF2B2 & $\mathrm{Hphl}$ & 313 & $\begin{array}{l}2 \text { fragments: } 310 \text { and } 3 \\
\text { bp. }\end{array}$ & $\begin{array}{l}4 \text { fragments: } 310,142 \text {, } \\
164 \text { and } 3 \text { bp. }\end{array}$ & $\begin{array}{l}3 \text { fragments: } 142,164 \\
\text { and } 3 \text { bp. }\end{array}$ \\
\hline C547T (RI83stop) & EIF2B2 & EcoNI & 253 & $\begin{array}{l}2 \text { fragments: } 120 \text { and } \\
133 \text { bp. }\end{array}$ & $\begin{array}{l}4 \text { fragments: } 120,133 \text {, } \\
14 \text { and } 119 \text { bp. }\end{array}$ & $\begin{array}{l}3 \text { fragments: } 120,14 \\
\text { and } 119 \mathrm{bp} .\end{array}$ \\
\hline A638G (E2I3G) & EIF2B2 & BsmAl & 313 & $\begin{array}{l}2 \text { fragments: } 153 \text { and } \\
160 \text { bp. }\end{array}$ & $\begin{array}{l}3 \text { fragments: } 313,160 \\
\text { and } 153 \text { bp. }\end{array}$ & I fragment: $313 \mathrm{bp}$ \\
\hline P243L (C728T) & EIF2B4 & Acil & 612 & $\begin{array}{l}3 \text { fragments: } 353,223 \\
\text { and } 36 \text { bp. }\end{array}$ & $\begin{array}{l}4 \text { fragments: } 576,353 \text {, } \\
223 \text { and } 36 \text { bp. }\end{array}$ & $\begin{array}{l}2 \text { fragments: } 576 \text { and } 36 \\
\text { bp. }\end{array}$ \\
\hline R374C (CII20T) & EIF2B4 & HpyCH4IV & 640 & $\begin{array}{l}2 \text { fragments: } 447 \text { and } \\
193 \text { bp. }\end{array}$ & $\begin{array}{l}3 \text { fragments: } 640,447 \\
\text { and } 193 \text { bp. }\end{array}$ & I fragment: $640 \mathrm{bp}$. \\
\hline TI393C (C465R) & EIF2B4 & BsrDI & 694 & $\begin{array}{l}3 \text { fragments: } 368,32 \\
\text { and } 294 \text { bp. }\end{array}$ & $\begin{array}{l}4 \text { fragments: } 368,32 \text {, } \\
294 \text { and } 326 \text { bp. }\end{array}$ & $\begin{array}{l}2 \text { fragments: } 368 \text { and } \\
326 \text { bp. }\end{array}$ \\
\hline TI465C (Y489H) & EIF2B4 & Nlalll & 707 & $\begin{array}{l}3 \text { fragments: } 109,310 \\
\text { and } 288 \text { bp. }\end{array}$ & $\begin{array}{l}5 \text { fragments: } 109,310 \text {, } \\
288,57 \text { and } 231 \mathrm{bp} \text {. }\end{array}$ & $\begin{array}{l}4 \text { fragments: } 109,310 \text {, } \\
57 \text { and } 231 \text { bp. }\end{array}$ \\
\hline G338A (RII3H) & EIF2B5 & Fnu4HI & 800 & $\begin{array}{l}3 \text { fragments: } 115,633 \\
\text { and } 52 \text { bp. }\end{array}$ & $\begin{array}{l}4 \text { fragments: } 115,633 \text {, } \\
52 \text { and } 748 \text { bp. }\end{array}$ & $\begin{array}{l}2 \text { fragments: } 748 \text { and } 52 \\
\text { bp. }\end{array}$ \\
\hline
\end{tabular}

* No mut: no mutation; Het mut: heterozygous mutation; Hom mut: homozygous mutation.

\section{Results}

None of the eight mutations already described in ovarioleukodystrophy were detected in our 93 patients with pure 46,XX POF, neither in a homozygous nor in a heterozygous state. In addition, the mutations C728T and C1120T (EIF2B4) described in milder forms of eIF2Brelated disorders were not found in this series of 93 patients with POF. The upper $95 \%$ confidence limit of the proportion $0 / 93$ is $3.2 \%$.

\section{Discussion}

eIF2B-related disorders include a large group of phenotypes with different clinical severities. Individuals can be classified into three clinical groups according to their age at disease onset: $<2$ years (group 1), 2 to 5 years (group 2) and $>5$ years (group 3 ) [11]. Group 3 corresponds to individuals with the milder form of the disease, including the six families (seven patients) already described presenting with ovarioleukodystrophy [9].

In these six eIF2B-mutated families, neurological symptoms with abnormalities of the cerebral white matter on MRI were associated with primary or secondary amenorrhea due to POF [9]. A correlation was observed between the age of onset of the neurological deterioration and the severity of the ovarian failure, suggesting a common pathophysiological pathway [9].
The mutated eIF2B may be responsible for both increased apoptosis of ovarian follicles leading to POF, and a defect in glial cell development causing abnormal formation of white matter structures. In ovarioleukodystrophy, a phase of amenorrhea without neurological symptoms can be observed, suggesting that an apparently isolated case of POF might be due to EIF2B mutations. In the present study, we tested for EIF2B mutations a series of 93 patients with pure, karyotypically normal POF without identified signs of cerebral dysfunction.

In eIF2B-related disorders, a correlation exists between genotype and disease onset [11]. The mutations G338A (EIF2B5 gene) and A638G (EIF2B2 gene) are found in $71 \%$ of families with late onset forms of eIF2B-related disorders (group 3) [11]. In ovarioleukodystrophy, 4/6 families have a G338A or A638G mutation in a heterozygote or a homozygote state. Thus, to further evaluate involvement of eIF2B mutations in apparently isolated cases of POF, we restricted our screening to the 10 mutations associated with the late onset form (group 3) of eIF2B-related disorders. In the present series of 93 patients with pure, karyotypically normal POF, no mutations were detected, suggesting a low frequency of EIF2B mutations in women with POF who have no apparent neurological signs. 


\section{Conclusions}

For patients presenting with POF without neurological signs or MRI abnormalities, the routine screening of the EIF2B mutations is not clinically indicated.

\section{Competing interests}

The author(s) declare that they have no competing interests.

\section{Authors'contributions}

$\mathrm{AF}$ and FGB carried out the molecular genetics studies, including enzyme restrictions (AF) and sequencing (AF and FGB). AF drafted and conceived of the study. RS participated in the coordination of the study. VHV, VKB, LMN recruited and evaluated the patients, collected DNA samples, participated in the design and coordination of the study, and helped in drafting the manuscript. OBT conceived of the study, and participated in its design and coordination. All authors participated in the writing of the manuscript and have read and approved the final manuscript.

\section{Acknowledgments}

We gratefully acknowledge the participation of the patients. This work was supported by a grant from the European Leukodystrophy Association (ELA), the Fondation pour la Recherche Médicale (FRM, ARS 2000) and the Jean Pierre and Nancy Boespflug myopathic research foundation.

\section{References}

I. Coulam CB, Adamson SC, Annegers JF: Incidence of premature ovarian failure. Obstet Gynecol 1986, 67:604-606.

2. Shelling AN: $\mathbf{X}$ chromosome defects and premature ovarian failure. Aust NZJ Med 2000, 30:5-7.

3. Conway GS: Premature ovarian failure. Curr Opin Obstet Gynecol 1997, 9:202-206.

4. Schlessinger D, Herrera L, Crisponi L, Mumm S, Percesepe A, Pellegrini M, Pilia G, Forabosco A: Genes and translocations involved in POF. Am J Med Genet 2002, I I I :328-333.

5. Shelling AN, Burton KA, Chand AL, van Ee CC, France IT, Farquhar CM, Milsom SR, Love DR, Gersak K, Aittomaki K, Winship IM: Inhibin: a candidate gene for premature ovarian failure. Hum Reprod 2000, I 5:2644-2649.

6. Aittomäki K, Lucena JL, Pakarinen P, Sistonen P, Tapanainen J, Gromoll J, Kaskikari R, Sankila EM, Lehvaslaiho H, Engel AR: Mutation in the follicle-stimulating hormone receptor gene causes hereditary hypergonadotropic ovarian failure. Cell 1995, 82:959-968.

7. Latronico AC, Anasti J, Arnhold IJ, Rapaport R, Mendonca BB, Bloise W, Castro M, Tsigos C, Chrousos GP: Brief report: testicular and ovarian resistance to luteinizing hormone caused by inactivating mutations of the luteinizing hormone-receptor gene. N Engl J Med 1996, 334:507-5I2.

8. Harris SE, Chand AL, Winship IM, Gersak K, Aittomäki K, Shelling AN: Identification of novel mutations in FOXL2 associated with premature ovarian failure. Mol Hum Reprod 2002, 8:729-733.

9. Fogli A, Rodriguez D, Eymard-Pierre E, Bouhour F, Labauge P, Meaney BF, Zeesman S, Kaneski CR, Schiffmann R, Boespflug-Tanguy O: Ovarian Failure Related to Eukaryotic Initiation Factor 2B Mutations. Am J Hum Genet 2003, 72: I544- I550.

10. Fogli A, Wong K, Eymard-Pierre E, Wenger J, Bouffard JP, Goldin E, Black DN, Boespflug-Tanguy O, Schiffmann R: Cree leukoencephalopathy and CACH/VWM disease are allelic at the EIF2B5 locus. Ann Neurol 2002, 52:506-5I0.

II. Fogli A, Schiffmann R, Bertini E, Ughetto S, Combes P, Eymard-Pierre E, Kaneski CR, Pineda M, Troncoso M, Uziel G, Surtees R, Pugin D,
Chaunu MP, Rodriguez D, Boespflug-Tanguy O: The effect of genotype on the natural history of elF2B-related leukodystrophies. Neurology 2004, 62:1509-1517.

\section{Pre-publication history}

The pre-publication history for this paper can be accessed here:

http://www.biomedcentral.com/1472-6874/4/8/prepub
Publish with Bio Med Central and every scientist can read your work free of charge

"BioMed Central will be the most significant development for disseminating the results of biomedical research in our lifetime. " Sir Paul Nurse, Cancer Research UK

Your research papers will be:

- available free of charge to the entire biomedical community

- peer reviewed and published immediately upon acceptance

- cited in PubMed and archived on PubMed Central

- yours - you keep the copyright

Submit your manuscript here:

http://www.biomedcentral.com/info/publishing_adv.asp
BioMedcentral 